Article

\title{
Design for Social Sustainability: Using Digital Fabrication in the Humanitarian and Development Sector
}

\author{
Lucia Corsini $*$ (D) and James Moultrie \\ Department of Engineering, University of Cambridge, Cambridge CB3 OFS, UK \\ * Correspondence: lc500@cam.ac.uk
}

Received: 28 May 2019; Accepted: 26 June 2019; Published: 28 June 2019

\begin{abstract}
The demand for humanitarian and development aid has risen to an unprecedented level in recent years. With a pressing need for new solutions, designers have started using digital fabrication (3D printing, $\mathrm{CNC}$ milling and laser cutting) to produce life-saving items. However, many organisations are failing to create the impacts they desire, and the social aspect of sustainability has been largely overlooked. This paper addresses this gap in knowledge by investigating guidelines for Design for Social Sustainability, specifically looking at digital fabrication for humanitarian and development projects. Building on existing literature and conducting three in-depth case studies of healthcare related products, the research develops a framework for Design for Social Sustainability. It provides useful guidelines to help plan and evaluate digital fabrication projects in the humanitarian and development sector. The findings show how design can trigger social sustainability at product, process and paradigm levels. Specifically, the case studies reveal the potential for digital fabrication to lead to more systems-focused, radical social sustainability. The paper concludes that an iterative and holistic approach to Design for Sustainability is needed, that begins by examining the social dimension first.
\end{abstract}

Keywords: social sustainability; digital fabrication; 3D printing; humanitarian; development; design for sustainability

\section{Introduction}

The demand for humanitarian and development aid has risen to an unprecedented level in recent years [1]. In a search for new solutions, designers have started using digital fabrication (3D printing, CNC milling and laser cutting) to produce life-saving items. In particular, the potential for digital fabrication to facilitate distributed manufacturing [2] and support the production of low-cost, customised products [3] has captured the imagination of the humanitarian and development sector [4]. Recently, digital fabrication has been used to produce a range of items including prosthetics, medical tools, emergency shelters, spare parts and communications infrastructure [5].

More broadly the sustainability of humanitarian and development projects is a well-known challenge [6-8]. Specifically, the sustainability of these digital fabrication interventions is a concern, with many organisations struggling to develop more than one-off products [5]. Whilst technology can promote radical social change and reduce poverty [9-11], it has also been criticised for 'shifting the burden' [12] and failing to address underlying social problems $[13,14]$. There is a growing recognition that sustainability is more than just the 'green agenda', and must consider social practices as part of a holistic approach $[15,16]$. Nonetheless, integrated approaches to sustainability have failed to examine social sustainability in adequate detail and have been criticised for being too broad [17]. 
In response to these concerns, research on social sustainability has increased in recent years [18]. However, Design for Social Sustainability (DfSS) remains a poorly understood concept $[19,20]$ and there is even less guidance on how to practically implement it [21,22]. Several projects aimed at creating social good have been criticised for not creating social sustainability. For example, Playpumps was a system for pumping water in rural Africa using a children's merry-go-round. It received the 2000 World Bank Development Market Place Award and secured over $\$ 60$ million in funding [23]. However, users were not consulted before the pumps were installed and children did not use the pumps to play. Instead, adults had to awkwardly turn the merry-go-round by hand to pump water, which was more difficult than using a traditional hand pump. The pumps were also expensive and difficult to maintain and Playpumps closed operations in 2010 after the project was deemed no longer sustainable [24].

Until DfSS is conceptually clarified and supporting guidelines are created, we cannot expect projects to achieve their ultimate goals of sustainability. This study addresses this lack of knowledge by investigating DfSS, from the perspective of digital fabrication projects in the humanitarian and development sector. The paper is structured as follows. First, we define DfSS and position DfSS in relation to associated design approaches. Second, we describe the methods used to investigate DfSS in digital fabrication for humanitarian/development (DF4D) projects. Third, we build on existing knowledge of DfSS and use three DF4D case studies to create a DfSS framework. This framework is intended to guide decision-making at the start of design process and product evaluation at the end of the design process. We evaluate the case studies using the DfSS framework to illustrate its value. They highlight how DF4D projects can support DfSS. In the discussion, we contextualise these findings within sustainability literature, to advocate for a holistic and iterative approach that begins with social sustainability. Finally, we discuss the theoretical and practical implications of the framework, pointing out areas for future research.

\section{What is Design for Social Sustainability (DfSS)?}

The challenges of defining social sustainability have been widely reported $[17,25-27]$ as it deals with social values that are complex, dynamic and difficult to quantify [28-30]. Recently, some notable works have improved our understanding of social sustainability. In particular, Einzenberg and Jabareen's [31] conceptualisation of social sustainability, Missimer et al.'s [16] investigation of the principles of social sustainability, Khan's [18] analysis of the themes of social sustainability and Benoitt et al.'s [32] work on the social life-cycle assessment. Within this paper, we consider social sustainability as: "the preservation of the social system, where people are not subject to structural obstacles to: health, influence, competence, impartiality and meaning-making" [16]. In other words, social sustainability is necessary to sustain positive change that addresses pressing social challenges. We use this definition to investigate DfSS, design that promotes social sustainability both in outcome and process.

Since William Morris published the first social design manifesto in 1873, calling for better quality products and social conditions during the Industrial Revolution, design has always played an important role in the preservation of social systems. As widespread industrialisation took hold in the $20^{\text {th }}$ century, several design practitioners including Buckminster Fuller, Victor Papanek and Nigel Whitely also advocated for a socially orientated design practice. Their calls for design to address "the real issues and concerns, rather than the phoney desires dreamt up by capitalist manufactures and their 'lackeys' ... industrial designers" [33], were manifested in the development of design approaches such as socially useful design, socially responsible design and social design.

Whereas these approaches focus largely on the creation of useful and accessible products that meet people's needs [33-37] and sometimes refer to economic, social and environmental issues [38,39], DfSS goes further to explicitly advocate for design that leads to the preservation of social systems and the removal of fundamental obstacles that destroy these systems. DfSS therefore calls for "processes and practices that lead to products whose lifecycles have a less negative impact on the social system" [40], providing "the prospect of humans flourishing on the earth forever" [41]. DfSS thus demands a multi-faceted approach which considers history, traditions, dialogue, equity and participation [42]. 
DfSS is naturally related to sustainable development, which is widely acknowledged in the Bruntland Report as "meeting the needs of the present without compromising the abilities of future generations to meet their needs" [43]. Whilst we do not believe that DfSS is explicitly for Bottom of Pyramid or Design for Development contexts, it is clear that DfSS addresses the marginalised in society $[14,44,45]$. In many ways, this is grounded in Papanek's original call for designers to spend time working on projects in the Global South [46]. As such, we consider DfSS an appropriate lens for studying the suitability of digital fabrication based projects in the humanitarian and development sector.

\section{Methods}

In order to address the lack of support for designers working on DF4D projects, we decided to create a DfSS framework that could help guide decision-making at the start of the design process and help to evaluate the social sustainability of products at the end of the design process. To begin with, a literature review was conducted in order to identify the key themes and contributing factors of DfSS. A number of initial search terms were identified related to design, social sustainability, and similar terms. Literature was gathered using Scopus and Google Scholar, with the following searches: "social sustainability" AND "design"; "design for social sustainability"; "socially sustainable design"; "design for social impact"; "design for sustainable social impact"; "design for sustainable social change"; "socially useful design"; "socially responsible design"; "sustainable product design". All articles were examined up until 2019 (March). When using Google Scholar, the first two pages for each search were retrieved for screening. This resulted in a total of 744 articles for review. An initial review of titles and, if necessary, abstracts was conducted to determine relevant papers. This resulted in the exclusion of 672 articles ( 34 were duplicates, 49 were not peer reviewed and 589 were irrelevant). At full paper review, 17 papers were removed as 11 papers were not relevant to social sustainability, and six papers were not relevant to design. This resulted in a total of 55 papers that met the criteria identified. A further nine papers were included using snowballing, resulting in a total of 64 papers.

Thematic analysis was selected to investigate the key themes of DfSS found within the literature. Thematic analysis is concerned with finding explicit ("semantic") and implicit ("latent") themes within data [47]. It is a useful approach for interpreting data in order to provide detailed accounts [48]. All the articles were read carefully and analysed according to their: key findings, terminology used (e.g., socially responsible design, design for sustainable development etc.), main focus (e.g., design education, design theory, design methods, metrics etc.), topics covered (e.g., participatory design, codesign, systems thinking, behavioural change etc.), methodology (e.g., case study, action research, interviews etc.) and research context (e.g., location, Global South/ Global North). This detailed analysis guided interpretation of the literature and key themes of DfSS were documented for each article. This resulted in an initial list of 46 themes. The key themes of DfSS were then analysed using a systematic process of defining categories and identifying the relationships between those categories in order to group conceptually similar themes [49]. This resulted in 36 sub-themes, which were further grouped into 15 themes. For example, the sub-themes 'democratic/ participatory', 'collaborative', 'cooperative', 'bottom up', and 'relational/ people focused' described the participation of different actors in the design process and therefore formed the higher level theme 'participatory'. Similarly, 'culturally sensitive design', 'situated design', 'appropriate technology' and 'local suitability' were concerned with design that is appropriate for the context and these themes were grouped together to form the key theme 'contextual'. This created a working list of DfSS key themes, shown in Table A1.

Next, to explore the relevance of these DfSS key themes to the DF4D context, three DF4D case studies were selected. Multiple case studies are a well-recognised way of gathering data about an emerging phenomenon [50]. These case studies were selected from a shortlist of case studies created by reviewing literature, conducting online searches, attending relevant conferences and word of mouth. The case studies were selected based on four criteria. First, the case study should use digital fabrication to produce products for humanitarian and development sector in low-income or lower-middle income countries. Second, the case study should be ongoing for sufficient duration to gather detailed 'live' 
data. Third, collectively the case studies should be related to a similar industry. Healthcare was selected as a common focus for DF4D projects. Finally, as a group the case studies were selected to represent DF4D projects in a range of organisations. For example, Field Ready are a non-profit engineering company, IIT Bombay are a university and Makerspace Nairobi are a makerspace.

Initial interviews were conducted with various members of the organisations over an eight month period to build up an understanding of the case studies. The first author visited case studies 1 and 2 between April and May 2018 and visited case study 3 in September 2018. The purpose of this data collection was two-fold. First, interviews were conducted with designers and project managers to identify the key themes of DfSS for DF4D projects. This was used to create the DfSS framework for DF4D projects. Second, information was gathered on the actual implementation of the DF4D projects, by conducting in-field observations and interviews with a range of stakeholders including partners, end users and beneficiaries. This provided data to later evaluate the DF4D projects using the DfSS framework. Table A2 provides a list of the interviewees and the interview protocols can be found in the Supplementary Materials.

The development of the DfSS framework took place iteratively. The interviews focusing on the enablers of DfSS were imported into MAXQDA for analysis. A code hierarchy was created based on the 15 themes and 36 sub-themes identified from the DfSS literature. During the first cycle of coding, line by line coding of the interview transcripts was conducted [51], resulting in 448 coded segments. Additional codes were created, and existing codes were also updated to reflect the language used by the interviewees. For example, the theme 'contextual' was renamed 'suitability'. During the second cycle of coding, further grouping and refinement of the codes was conducted, resulting in the 16 factors shown in the final DfSS for DF4D framework (see Figure 2).

The next stage of coding further examined the relationships between these 16 factors. After several discussions between the authors, it was found that the 16 factors could be broadly grouped in three categories. The first set of factors were directly concerned with the physical product's attributes and were called product factors. The next set of factors were related to the management of the design process and were grouped as process factors. The final set of factors facilitated new ways of doing things or thinking about things and formed the category paradigm factors.

The DfSS framework was then used to evaluate the selected DF4D projects from the case studies. This was shared with all the organisations and feedback on the framework's value was collected. Figure 1 provides an overview of this process.

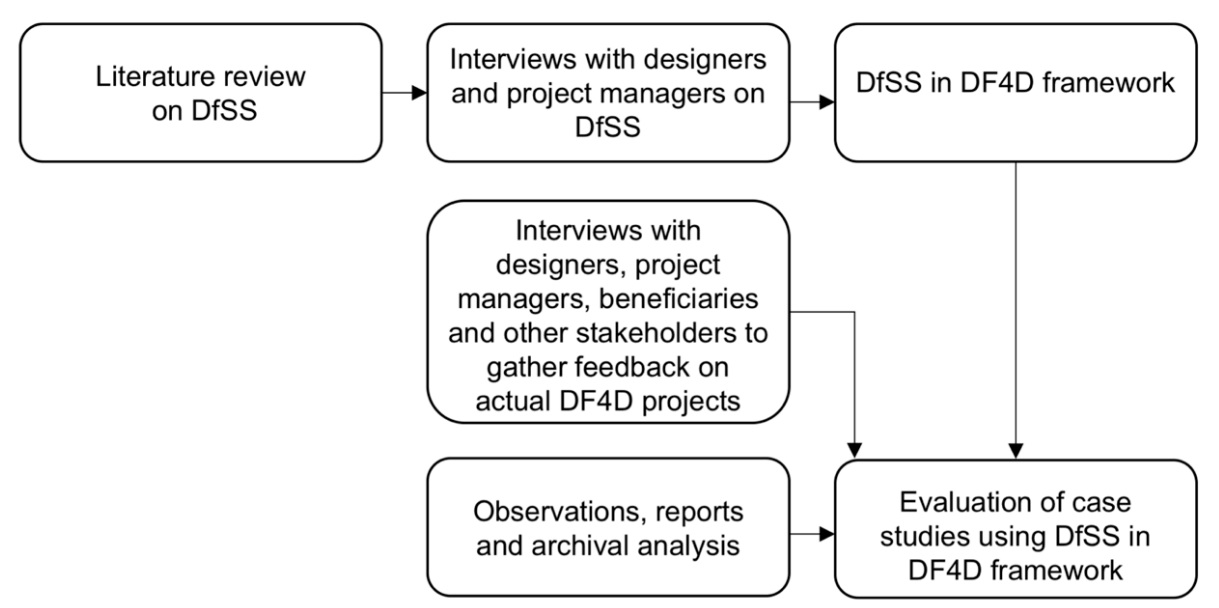

Figure 1. Approach for creating framework on Design for Social Sustainability (DfSS) in Digital Fabrication for Development (DF4D).

\section{Results}

The following section presents the DfSS framework aimed at designers working on DF4D projects. It is intended to help guide decision making at the start of the design process and to help evaluate 
the social sustainability of products at the end of the design process, providing an opportunity to reflect on future practices. Supporting questions were identified for each factor, to encourage reflection. Whilst this framework suggests a way forward for DfSS, the questions are purposely open-ended and qualitative to avoid overly prescriptive criteria that overlook the complex and contextually-dependent realities of DF4D projects. Example quotes from interviewees to justify the importance of each factor can be found in Table A3. Following a brief description of the DfSS framework, the following section will demonstrate its value by using it to analyse the case studies.

\subsection{DfSS Framework for DF4D Projects}

The DfSS framework identifies 16 criteria related to product, process and paradigm factors (see Figure 2). Rather than suggesting a hierarchy, we emphasise that all three categories (product, process and paradigm) must be considered in order to achieve social sustainability. Simply, we do not believe that social sustainability can exist without addressing all three dimensions from the start of DF4D projects.

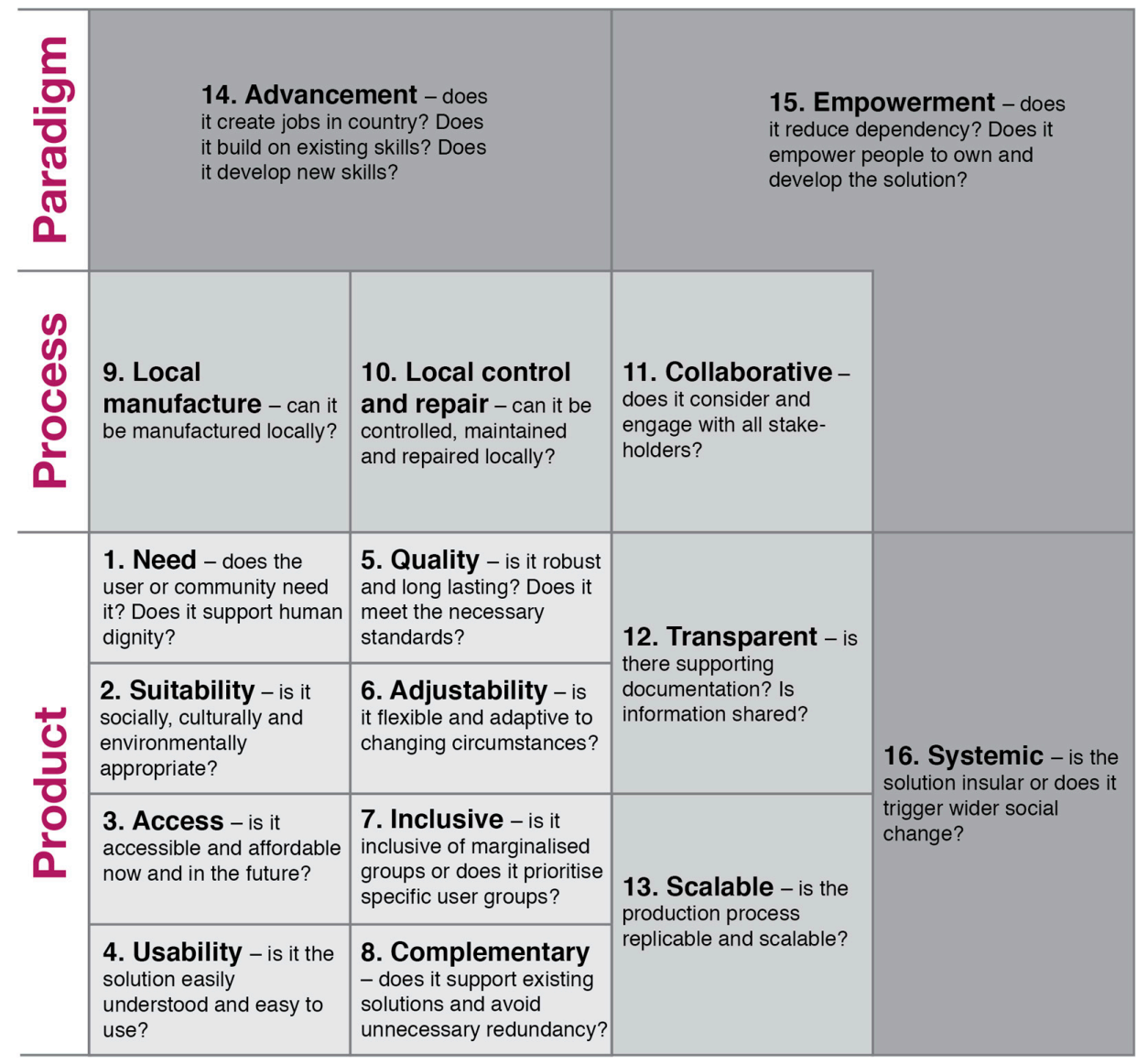

Figure 2. Design for Social Sustainability framework, for DF4D projects.

The first set of factors in the DfSS framework are related to product itself: need; suitability; access; usability; quality; adjustability; inclusivity; and, complementary. These reflect more incremental approaches to DfSS that focus on user-orientated ways of promoting social sustainability. The second set of factors are related to the design process, including local manufacture; local control and repair; collaborative; transparent; scalable. The final set of factors are related to paradigms: advancement; empowerment; systemic. They demand different ways of doing things and thinking about things. The findings emphasise that as DfSS progresses from product to process to paradigm factors, social sustainability becomes more radical versus incremental, and more system-focused versus user-focused. Figure 3a provides a summary of this proposition. 


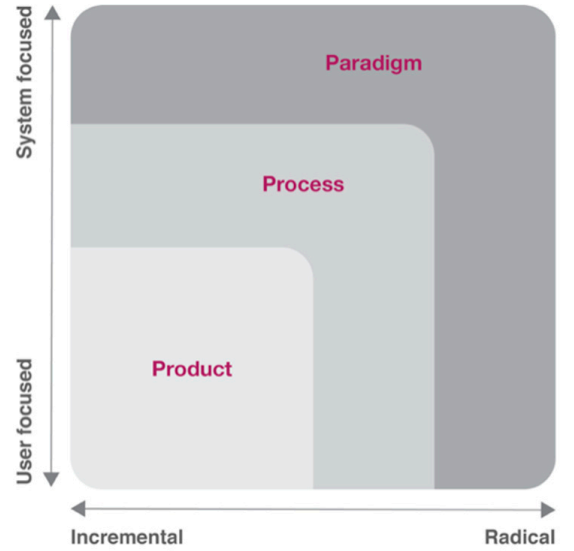

(a)

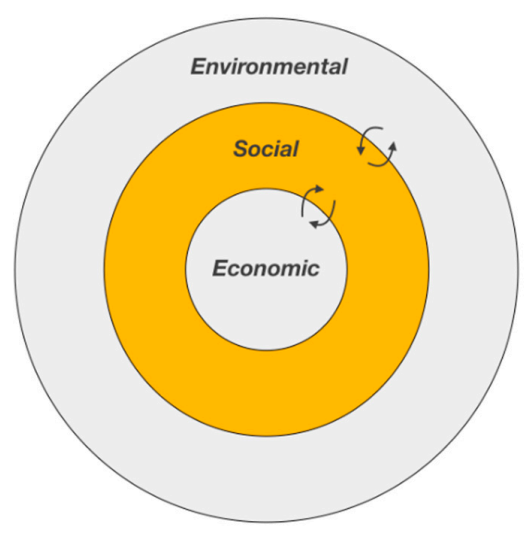

(b)

Figure 3. (a) Shifting towards more system-focused and radical Design for Social Sustainability; (b) positioning DfSS within the broader sustainability context.

In developing this framework, we position social sustainability within environmental and economic sustainability (see Figure 3b). We suggest that designers begin with this addressing DfSS and then consider the impacts on environmental and economic sustainability. Where necessary, iterative adjustments can be made to social dimensions to reach a balance between sustainability as a whole.

\subsection{Evaluation of Case Studies Using DfSS Framework}

\subsubsection{Field Ready-3D Printing a Spare Part for a Suction Pump Machine}

Field Ready are a non-profit humanitarian organisation that is pioneering the use of digital fabrication and local manufacture of humanitarian supplies. They produced a spare part to repair a broken suction pump machine, a medical device that is used to clear fluid from patients. They designed and manufactured the product on-site during a visit to a rural health post in Nepal, when they discovered a broken connector on a suction pump machine. The health post could only repair the machine by purchasing a replacement of the entire unit, which was expensive and difficult for the health post to procure. Field Ready were able to design and 3D print the spare part on-site within a few hours.

Considering the DfSS framework, the spare part immediately fulfils user needs by replacing a life-saving, expensive machine. As a bespoke fix, it is designed specifically for its use-context (suitability) and is naturally complementary to the existing suction pump machine. Producing the part at the health post eliminates barriers to access, with the cost of producing the part estimated to be $90 \%$ less than the alternative replacement (access). Local manufacture eliminated typical procurement challenges and enabled more participatory engagement from the end users (collaborative). After producing the part, Field Ready shared the design on Thingiverse, so that other health posts could replicate the part and adjust it as needed (adjustability, transparent). Still, scalability is limited by lack of available infrastructure at other health posts.

Although this case study addresses the short-term needs of users, it falls short of delivering more long-term social sustainability. The quality of the part was verified upon implementation, however, the durability of the part is unknown and no follow up was taken. By locally manufacturing the part, the health post are less dependent on importing goods, however they instead become dependent on Field Ready providing a product-service (empowerment). The health post cannot maintain or repair the part themselves (local control and repair), and there is little capacity building beyond the Field Ready team as a result of the project (advancement). Additionally, whilst production is local in that the part is designed and printed on-site, materials, technologies and human capital are mainly 'imported' (using non-local staff). 
Considering the DfSS framework (see Figure 4), Field Ready should prioritise quality and empowerment, and also consider advancement, local control and repair, and scalability. By investing in local capacity building, Field Ready can begin to address these factors simultaneously. Ultimately, this marks a significant shift away from traditional problem-solving to capacity building. Similarly, humanitarian aid must move away from traditional models of providing aid to empowering beneficiaries.

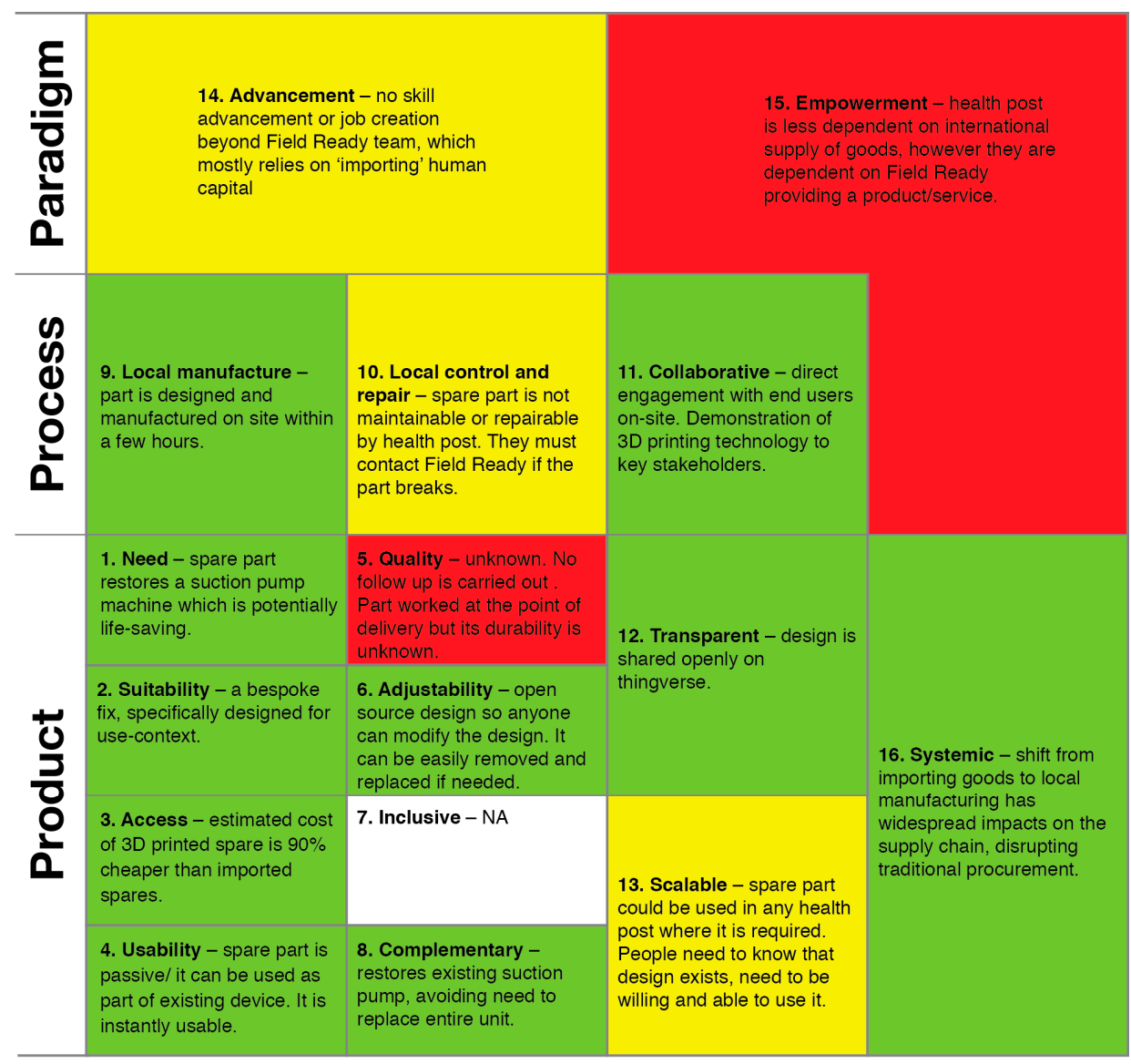

Figure 4. Evaluation of Field Ready-3D printed spare part.

3.2.2. Indian Institute of Technology-Bombay (IIT-B)—3D Printing or CNC Milling a Socket for a Leg Prosthetic

Since the Jaipur Foot prosthetic was developed over 50 years ago, more than 22 facilities across India produce the unpatented, low cost leg prosthetic. Ratna Nidhi Charitable Trust (RNCT) is a charitable trust in Mumbai that manufactures the Jaipur Foot prosthetic. The CEO of RNCT approached the Indian Institute of Technology-Bombay (IIT-B) to investigate how new technologies could scale-up the manufacturing process of the Jaipur Foot, to provide more beneficiaries with access to the prosthetics. In partnership with google.org, the project has been exploring the potential of 3D printing and CNC milling to create a low-cost, customised socket for the leg prosthetic. As of the beginning of 2019, patient trials are currently being conducted to test the CNC-manufactured sockets.

The new digitally fabricated socket is specifically designed to complement the existing Jaipur Foot, therefore avoiding unnecessary redundancy. Throughout the project, decisions have been made to support local manufacture, control and repair. For example, the use of 3D scanning was ruled out, as the cost is prohibitive for scaling-up the new socket design to other trusts. The design of the socket has been carefully considered such that it can be easily produced by the existing workforce. Throughout the project, transparency has been important and detailed documentation has been created to facilitate local production. In this way, the advancement of the workforce has also been addressed. 
In addition, the project promotes greater systemic impacts. IIT-B have been advancing the Indian digital fabrication ecosystem by collaborating with Indian start-ups that are developing production tools and materials. For example, they have established a relationship with AHA 3D, an Indian manufacturer of 3D printers. By using AHA's 3D printers, they have supported the printer's development and promoted their brand. Similarly, they have collaborated with Fractal Works, another Indian based company that provides 3D printing filament. These collaborations reveal how this case study has cultivated an entrepreneurial ecosystem, thus triggering wider social change (systemic). Overall, the focus on local ownership supports the empowerment of users and providers.

As a whole, the project reveals a more system-focused and radical approach to social sustainability, with paradigm-related factors being considered from the start. One weakness that the DfSS framework reveals (see Figure 5) is that this project is primarily focused on the needs of the charitable trust (i.e., scaling up the production process) rather than the primary needs of the users (which include demands for more aesthetic and light weight prosthetics). Furthermore, collaboration on the implementor side has been limited to one charitable trust, which may limit replication at other locations and present a barrier to scalability. In order to drive more socially sustainable outcomes, the project should address these factors (need, collaboration and scalability), and remain mindful of concerns around access and quality, which are unknown at present.

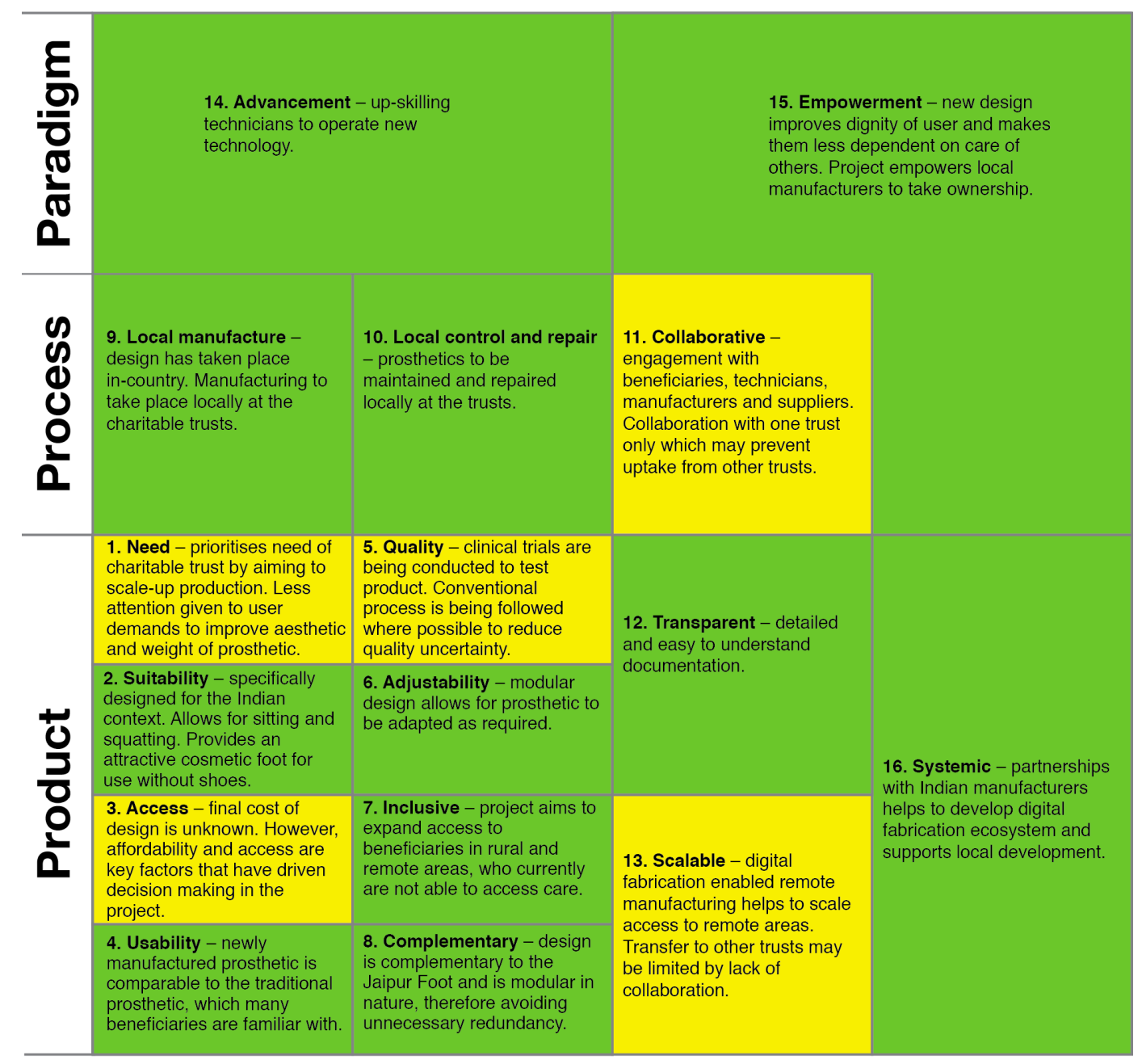

Figure 5. Evaluation of the Indian Institute of Technology-Bombay (IIT-B)—CNC manufactured socket for leg prosthetic. 


\subsubsection{FabLab/MakerSpace Nairobi-Digitally Fabricating a Low Cost Suction Pump Machine}

Concern Worldwide approached FabLab Nairobi in 2013 after they recognised the potential for the makerspace to develop affordable medical devices in Kenya. They formed a partnership to develop technologies that support maternal and new born healthcare. They established a larger facility, MakerSpace Nairobi in 2016 to manage the project, and worked with Kenyatta National Hospital to design and manufacture a low cost suction pump machine that could be manufactured in Kenya. In 2017, The Phillips Foundation and UNICEF joined as partners.

The suction pump machine is a potentially life-saving device that helps to prevent the spread of infection and clear obstructions during resuscitation. The lack of available suction pumps was identified as a key challenge by the maternity ward at Kenyatta National Hospital (need). 3D printing has been used to manufacture the casing for the glass containers and water jet CNC cutting has been used to produce the metal casing. Clinical trials of the product are currently being conducted at Kenyatta National Hospital (quality).

The case study uses design to promote social sustainability across a number of criteria. The suction pump machine has been designed specifically for use in the local context, where rugged castors have replaced original castors to account for uneven flooring and the height of device is designed for average African nurse (suitability). Furthermore, the machine has been designed to be suitable for a range of beneficiaries, including adults and children (inclusive). Features in the previously imported model of the suction pump machine have been removed to prevent misuse. For example, nurses previously pulled on the machine's wire cable to transport the device, however this has been replaced with an ergonomic handle and a detachable wire cable, which will disconnect from the device if pulled on (usability). So far, current estimates show that the locally manufactured machine will cost approximately $70 \%$ of the imported suction pump machine (access).

Local control and repair also reduces the need to import spare parts, which is a major procurement challenge for Kenyan hospitals. The product itself is highly modular, to improve the ease of repair (adjustable). The project has also facilitated a highly participatory process in which designer, engineers, procurement officers, hospital managers and medical professionals have been deeply engaged (collaborative). In addition, the makerspace have established collaborations with local manufacturers. Collaborating with influential partners is expected to support implementation at multiple healthcare facilities (scalable). Still, some parts are necessary to import as they cannot be sourced locally (including pressure gauges), highlighting barriers to local manufacture in this context.

As well as fulfilling product and process related DfSS criteria, this case study highlights the potential for more far-reaching, paradigm impacts. Advancement is recognised in two major ways. First, local manufacture of suction pump machine offers the potential for direct job creation. Second, the project supports the development and training of local manufacturers, students and clinical staff. The Maker Project has been significantly empowering for participants, including the clinical staff who feel ownership of the device. More importantly, it challenges the attitudes of people in Kenya towards local production and underlines the potential of local capabilities, leading to systemic impacts. The project itself sets precedent for manufacturing medical devices in Kenya and is aligned with broader goals set in the Kenyan government's 2018 Big Four agenda, which lists manufacturing and affordable healthcare as focus areas.

Reflecting on the DfSS framework (see Figure 6), we can see that the majority of factors have been addressed and that paradigm-related factors have been embedded throughout the project. The evaluation does however flag concerns related to transparency. Whilst the project has been well documented throughout, exact ownership of intellectual property is unclear due to the involvement of multiple partners at different stages in the project. There is an urgent need to address this factor to ensure the viability of the project in the future. 


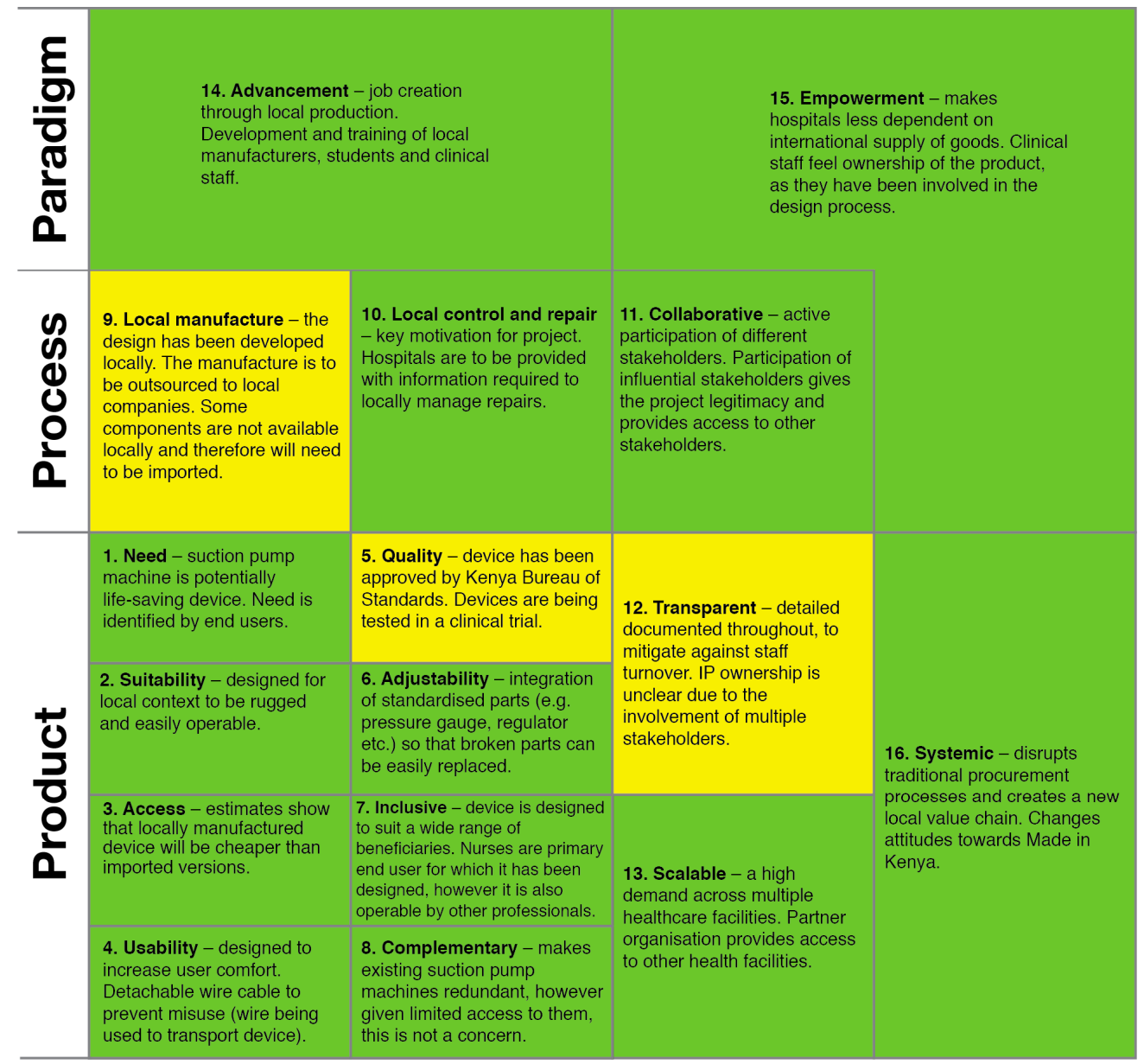

Figure 6. Evaluation of FabLab/Makerspace Nairobi-digitally fabricated suction pump machine.

\section{Discussion}

\subsection{Summary of the Case Studies}

This study reveals that DF4D can support social sustainability, however social sustainability is not an inevitable outcome. Across the case studies, we find that there is a general shift towards local production, which supports more participatory and contextually appropriate outcomes. We also find that DF4D can trigger wider social change. In cases 2 (socket for a leg prosthetic) and 3 (suction pump machine) digital fabrication responds to the explicit demand for products, as well as creating new infrastructure that advances local employment, empowerment and ownership. These projects reveal how DF4D can create systems-focused and radical social sustainability. In contrast, the first case study (3D printed spare part for a suction pump machine) results in limited advancement of local skills, local control and empowerment. This project provides a 'quick win' solution which is relatively incremental and user-focused. Overall, this comparison draws attention to the need for more long-term, open ended solutions in which sustainability is embedded early on [45,52,53].

Whilst the cases show the potential for DF4D, we also note that these projects tend to operate as isolated examples, rather than as "constellations of design initiatives geared toward making social innovation more probable, effective, long-lasting, and apt to spread" [54]. In short, there is a need for more scalable and transparent ways of working in DF4D projects. We know that greater collaboration has been shown to support sustainability between maker initiatives [55] and that open sustainable innovation [56], including peer to peer networks, can facilitate sustainable outcomes. However, analysis of the cases using the DfSS framework show that this is happening on a rather limited scale. The creation of platforms to mobilise local resources [57] and the development of more collaborative and network-based 
initiatives may go some way to addressing this $[20,58]$. However, there also needs to be a fundamental willingness to do things differently in the humanitarian and development sector.

\subsection{Theoretical Implications of the DfSS Framework for DF4D Projects}

Our research reveals the important role of design in promoting social sustainability. Design can be both a source of un-sustainability and a means for achieving sustainability $[33,59]$. This study expands current knowledge on DfSS and provides a DfSS framework, specifically aimed at designers working on DF4D projects. By focusing on social sustainability, we attempt to address the limited research in this area. Nonetheless, we acknowledge that economic, environmental and social dimensions are inherently related and interdependent [15]. In developing our DfSS framework, we suggest that designers begin by examining the social dimension of sustainability [60], and then consider the implications on economic and environmental dimensions. This feedback can be used to continuously adjust decision making in the design process, until an optimum scenario is reached for sustainability as a whole. This offers an alternative to the current "win-win" logic, which positions economic, social and environmental aspects of sustainability as equal, but in practice maximises economic benefits [61].

Within the DfSS framework, we present product, process and paradigm factors as three necessary dimensions that must be fulfilled to achieve social sustainability. The identification of product factors builds on existing approaches to Design for Sustainability that focus on quality, usability, durability and inclusive design [62]. Central to much of this dialogue is the increasing focus on user needs $[44,52,63]$ which are recognised as being contextual and situated $[64,65]$. This leads to the process factors which confirm normative arguments that DfSS is participatory $[45,66,67]$ democratic $[68,69]$ and cultivates local ownership [37,70]. Finally, the paradigm factors complement theories on agency and postcolonialism, which suggest that imported technologies increase dependency on aid and undermine local knowledge [71,72]. In contrast, our framework advocates the development of local capabilities, which empower people to develop and own solutions. Whilst Design for Sustainability has mainly focused on product factors and to some extent process factors, our framework highlights that DfSS demands the equal attention of product, process and paradigm factors. Simply, we do not believe that social sustainability can exist without addressing all three dimensions.

We propose that the integration of these three dimensions marks a shift towards more systems-focused DfSS. Systems design recognises the complex, interrelated nature of the world. It rejects reductionist epistemics, adopting a holistic view in which 'the whole is more than the sum of its parts' [73]. Notably, systems design draws attention to desired outcomes and goals, rather than specific products or technologies [74]. Similarly, in the DfSS framework we suggest that the inclusion of product, process and paradigm factors allows designers to work towards the broader goal of sustainable development. The DfSS framework specifically encourages designers to create solutions that are not just user-focused but are systems-focused. Rather than focusing on how products can solve people's needs, we draw attention to how the entire product lifecycle (including design, manufacture, use and maintenance) can maximise social impact.

Drawing on theory from socio-technical systems, we argue that the inclusion of product, process and paradigm factors creates the possibility for more radical DfSS. According to Freeman and Perez [75], radical solutions often combine product, process and organisational innovations. Radical solutions can also trigger new markets, which in the context of DF4D projects could be the demand for locally designed products. Geels and Schot [76] explains that radical solutions provide an opportunity to challenge the socio-technical regime. Therefore, solutions that challenge traditional models of aid in favour of advancement, empowerment and systemic change necessitate radical solutions. Overall, these findings suggest that strong sustainability must address the underlying causes of un-sustainability [63]. Simply, incremental solutions will not suffice, and wide-scale change should be embedded within ambitions for social sustainability [77]. 


\subsection{Practical Implications of DfSS Framework for DF4D Projects}

For practitioners working on DF4D projects, our framework provides useful guidelines for planning and assessing projects. Instead of just focussing on product performance factors, we encourage designers to look more broadly at how the entire product lifecycle can maximise social sustainability. Overall, this shifts thinking away from short-term to long-term goals.

To assess the value of the DfSS framework it was shown to practitioners for their feedback. The case studies were also discussed with practitioners, highlighting its potential for stimulating reflection. Their feedback confirmed the value of framework, during the planning stage and evaluation stage of the design process. The practitioners explained how the framework would improve their current practice and how they would do things differently. Specifically, they believed that the framework would encourage them to think about the broader impacts of their interventions and to avoid a narrow product focus. Furthermore, they felt that the framework would help them to identify areas that had been overlooked in ongoing projects.

- Engineers want to fix the engineering problem. They normally fix what they can fix rather than looking at the wider scope and thinking about the value of fixing that thing. Say in a hospital this could help them to think about what the most valuable thing is to the health care practitioner rather than 'here is a broken fuse, let me fix it'." (Innovation Advisor, case study 1) The organisations were interested in using the framework in their future projects and in the next stage of this research we plan to run a pilot to test the DfSS framework in DF4D projects.

- I can see us using this, I can see this framework having some great utility ... One of the things that we often struggle with is how to prioritise projects ... this could help ... It intuitively makes sense at the start of the design process, but it would also provide a useful check at the end." (Innovation Lead, case study 1)

- I think you have captured some of the most important criteria ... I can see this being used as a sustainable design version of the business canvas tool." (Project leader and engineer, case study 2)

- I think this framework is really useful. It captures all the aspects that we encourage students to think about during hackathons ... We definitely could use this to help plan projects." (Makerspace manager and designer, case study 3 )

\section{Conclusions}

Digital fabrication offers a new way of solving 'wicked problems' found in the humanitarian and development sector. However, to date, many interventions have failed to deliver long-term sustainability. This paper has addressed a concern that little attention has been given to the social dimension of sustainability, which is limiting sustainable development in the humanitarian and development sector. We have explored how design can promote social sustainability and investigated the ways in which designers can practically Design for Social Sustainability (DfSS). We conducted a review of literature related to DfSS and selected three case studies that use digital fabrication to produce healthcare related products in the humanitarian and development sector. This led to the creation of a DfSS framework, specifically for projects using digital fabrication in the humanitarian/ development sector (DF4D). This framework was used to evaluate the case studies, to reveal how digital fabrication can support socially sustainable outcomes.

This study significantly contributes to our knowledge on DfSS, however there are some limitations which may affect our findings. First, we acknowledge that this is an emerging field, in which definitions of social sustainability are still being clarified. Second, our findings are the result of a small number of case studies that are producing healthcare related items. As DF4D projects are increasing in number and in range of application, we recommend that additional DF4D case studies are selected from other sectors to further test this framework. Second, although the case studies are located in low-income and lower-middle income countries, they vary in geographical location. Future work could replicate this work in a specific region or consider the relevance of these findings to 
non-humanitarian/development contexts. We urge researchers to examine the relevance of this DfSS framework more broadly, considering its application to the development of products that do not use digital fabrication tools.

Overall, this study shows how design can trigger social sustainability at product, process and paradigm levels. Our findings signal a shift from user-related to systems-related, and from incremental to radical social sustainability. We argue that an iterative and holistic approach to sustainability is needed, that begins by examining the social dimension first. For practitioners working on DF4D projects, we provide a useful framework to help plan and evaluate projects, to support Design for Socially Sustainability.

Supplementary Materials: The following are available online at http://www.mdpi.com/2071-1050/11/13/3562/s1, Table S1: Interview protocol to identify themes of DfSS for DF4D Projects, Table S2: Interview protocol to gather actual data on DF4D Projects.

Author Contributions: Conceptualization, L.C.; methodology, L.C.; validation, L.C.; investigation, L.C.; data curation, L.C.; writing—original draft preparation, L.C.; writing—review and editing, L.C. and J.M.; visualization, L.C. and J.M.; supervision, J.M.; project administration, L.C.; funding acquisition, L.C.

Funding: Funded by UK EPSRC Doctoral Training Programme, grant number EP/L504920/1 and School of Technology Travel Award, University of Cambridge, UK.

Acknowledgments: The authors would like to thank all the participants and Anitha Srinvasa for providing translation assistance. We would also like to thank the anonymous reviewers for their helpful comments in improving this paper.

Conflicts of Interest: The authors declare no conflict of interest.

\section{Appendix A}

Table A1. Themes of DfSS found in the literature.

\begin{tabular}{|c|c|c|}
\hline Theme & Sub-Theme & Citations \\
\hline \multirow{5}{*}{ Systemic } & Long-term approach & $\begin{array}{l}\text { Cooley [34], Hillgren et al. [45], Stairs [64], Bjögvinsson et al. [66], } \\
\text { Clark et al. [78] }\end{array}$ \\
\hline & Systemic/holistic & $\begin{array}{l}\text { Vezzoli [20], Bhamra [11], Cooley [34], De Vere et al. [36], Stairs [64], } \\
\text { Melles et al. [63], Clark et al. [78], Manzini and Vezzoli [79], Howarth } \\
\text { and Hadfield [80], De Vere et al. [81], Chick [82], Cipolla and Bartholo } \\
\text { [83], Vezzoli et al. [84], Ceschin et al. [85], Koskinen and Hush [86] }\end{array}$ \\
\hline & Catalyses social change & Gamman and Thorpe [87] \\
\hline & Full-life cycle & Maxwell and Van der Vorst [88], Dewulf [89] \\
\hline & Product and process & Hanusch and Birkhoefer [90] \\
\hline \multirow{3}{*}{ Empowerment } & Empowering/emancipatory & $\begin{array}{l}\text { Cooley [34], Caruso and Frankel [37], Bezerra and Brasell-Jones [65], } \\
\text { Smith and Iverson [69], Cipolla and Bartholo [83], Amatullo et al. [91] }\end{array}$ \\
\hline & Local control/local ownership & Thomas [52], Melles et al. [63] \\
\hline & Agency & Er and Kaya [72], Kadir and Jamaludin [92] \\
\hline \multirow{3}{*}{$\begin{array}{l}\text { Employment, } \\
\text { skills and } \\
\text { education }\end{array}$} & Job creation/employment & Cooley [34], Thomas [52], Melles et al. [63], Amatullo et al. [91] \\
\hline & $\begin{array}{l}\text { Educational/advancing local } \\
\text { knowledge }\end{array}$ & $\begin{array}{c}\text { Morelli [59], Melles et al. [63], Bezerra and Brasell-Jones [65], } \\
\text { Bjögvinsson et al. [66], Amatullo et al. [91] }\end{array}$ \\
\hline & Capacity building & Yee and White [93] \\
\hline \multirow[t]{4}{*}{ Participatory } & Participatory/democratic & $\begin{array}{l}\text { Cooley [34], De Vere et al. [36], Margolin and Margolin [44], } \\
\text { Hillgren et al. [45], Melles et al. [63], Stairs [64], Bjögvinsson et al. [66], } \\
\text { Chick [82], Morelli [59], Smith and Iverson [69], Kang [70], Cipolla and } \\
\text { Bartholo [83], Amatullo et al. [91], Manzini [94], Margolin [95], Asheim } \\
\text { et al. [96], Manzini [97], Melles et al. [98], Chen and Cheng [99], } \\
\text { Lie [100], Mendoza et al. [101] }\end{array}$ \\
\hline & Collaborative/cooperative & $\begin{array}{c}\text { Cooley [34], McMahon and Bhamra [42], Melles et al. [63], Sklar [102], } \\
\text { Gmelin and Seuring [103], McMahon and Bhamra [104] }\end{array}$ \\
\hline & Bottom up & Manzini [54], Melles et al. [98] \\
\hline & People focussed/relational & De Vere et al. [36], Hillgren et al. [45], \\
\hline
\end{tabular}


Table A1. Cont.

\begin{tabular}{|c|c|c|}
\hline Theme & Sub-Theme & Citations \\
\hline \multirow{3}{*}{ Wellbeing } & Needs-based & $\begin{array}{l}\text { Rose [14], Cooley [34], Margolin and Margolin [44], Thomas [52], } \\
\text { Melles et al. [63], Cipolla and Bartholo [83] }\end{array}$ \\
\hline & Preventing harm/reducing harm & Thomas [52], Bezerra and Brasell-Jones [65], Haug [105] \\
\hline & Promoting wellbeing & Mendoza et al. [101] \\
\hline \multirow{3}{*}{ Responsive } & Reflective & McMahon and Bhamra [42] \\
\hline & Empathetic & $\begin{array}{c}\text { Caruso and Frankel [37], Cipolla and Bartholo [83], Sklar [102], } \\
\text { Schaber [106] }\end{array}$ \\
\hline & Ethical & Koo and Cooper [39], Koo [107] \\
\hline \multirow[t]{4}{*}{ Contextual } & Local suitability & $\begin{array}{l}\text { Cooley [34], McMahon and Bhamra [42], Margolin and Margolin [44], } \\
\text { Hillgren et al. [45], Morelli [59], Melles et al. [63], Stairs [64], } \\
\text { Bjögvinsson et al. [66], Kang [70], Chick [82], Cipolla and Bartholo [83], } \\
\text { Amatullo et al. [91], Asheim et al. [96], Manzini [97], Melles et al. [98], } \\
\text { Gmelin and Seuring [103], McMahon and Bhamra [104] }\end{array}$ \\
\hline & Culturally sensitive design & $\begin{array}{l}\text { Vezzoli [20], De Vere et al. [81], Kadir and Jamaludin [92], Margolin [95], } \\
\text { Woodcraft [108] }\end{array}$ \\
\hline & Appropriate technology & Lie [100], Sklar [102], \\
\hline & Situated design & Kang [70], Cipolla and Bartholo [83] \\
\hline Local & Local design & $\begin{array}{l}\text { Vezzoli [20], Manzini [54], Morelli [59], Melles et al. [63], Stairs [64], } \\
\text { Thorpe and Gamman [68], Morelli [59], De Vere et al. [81], Manzini [94], } \\
\text { Melles et al. [98], Manzini [97] }\end{array}$ \\
\hline Product-led & Product-led & Lilley [53] \\
\hline Manufacturable & Manufacturability & Thomas [52] \\
\hline Affordable & Affordability & Thomas [52], Melles et al. [63], \\
\hline $\begin{array}{l}\text { Supporting } \\
\text { economic security }\end{array}$ & Financial independence & Cooley [34], Thomas [52], Amatullo et al. [91] \\
\hline Usability & Usability & Melles et al. [63] \\
\hline \multirow{2}{*}{ Inclusivity } & Inclusive & Cipolla and Bartholo [83], Kadir and Jamaludin [92] \\
\hline & Accessibility & Kadir and Jamaludin [92] \\
\hline \multirow{3}{*}{ Distributed } & Distributed design/networks & Vezzoli [20], Morelli [59], Manzini [94], Manzini [97], Melles et al. [98] \\
\hline & Open/connected & Manzini [94], Manzini [97] \\
\hline & Small/local scale & Chen and Cheng [99] \\
\hline
\end{tabular}

Table A2. Interviewee details and codes.

\begin{tabular}{cc}
\hline Case Study & Interviewee Role and Codes \\
\hline 1. Field Ready & $\begin{array}{c}\text { Project manager (CS1-01), Designer (CS1-02), Designer (CS1-03), Junior designer } \\
\text { (CS1-04), Junior designer (CS1-05), Monitoring and evaluation lead (CS1-06), } \\
\text { Innovation Advisor (CS1-07) }\end{array}$ \\
\hline & $\begin{array}{c}\text { Project lead and engineer at IIT-B (CS2-01), Physiotherapist at IIT-B (CS2-02), } \\
\text { Designer at IIT-B (CS2-03), Junior designer at IIT-B (CS2-04), CEO at RNCT } \\
\text { (CS2-05), Prosthetist and Orthotist at RNCT (CS2-06), Production technician at }\end{array}$ \\
2. Indian Institute of & RNCT (CS2-07), Production technicians at RNCT (CS2-08), Beneficiary 1 at RNCT \\
Technology-Bombay (IIT-B), Ratna & (CS2-09), Beneficiary 2 at RNCT (CS2-10), CEO, founder of BMVSS (CS2-11), \\
Nidhi Charitable Trust (RNCT), & Technical consultant at BMVSS (CS2-12), Prosthetist and Orthotist at BMVSS \\
BMVSS Trust & (CS2-13), Technician at Jaipur Foot (CS2-14), Project manager at BMVSS (CS2-15), \\
& Secretary at BMVSS (CS2-16), Beneficiary 1 at BMVSS (CS2-17), Beneficiary 2 at \\
& BMVSS (CS2-18), Beneficiary 3 at BMVSS (CS2-19), Beneficiary 4 at BMVSS \\
& (CS2-20), Beneficiary 5 at BMVSS (CS2-21), Beneficiary 6 at BMVSS (CS2-22) \\
\hline MakerSpace Nairobi, Kenyatta & MakerSpace manager and designer (CS3-01), Lead designer at MakerSpace \\
National Hospital (KNH) & (CS3-02), Designer at MakerSpace (CS3-03), Project manager at KNH (CS3-04), \\
& Project administrator at KNH (CS3-05), Project data manager at KNH (CS3-06), \\
& Deputy head nurse at KNH (CS3-07), Biomedical engineer at KNH (CS3-08) \\
\hline
\end{tabular}


Table A3. Exemplary quotes to justify Design for Social Sustainability framework.

\begin{tabular}{cc}
\hline Factor & Exemplary Quotes \\
\hline 1. Need & $\begin{array}{c}\text { "Obviously, addressing the need is where we start and hopefully finish. There has to be } \\
\text { understanding of the problem that needs to be solved and how your intervention and your } \\
\text { approach is actually addressing that problem. I said we're focusing on products, but actually } \\
\text { those products are a reflection of how we are addressing a need." CS1-01 }\end{array}$ \\
\hline
\end{tabular}

"Sometimes when you make something you make it to suit a certain environment. So it works well in that environment, but it may not work very well in a different setup. So that's also part of it, you want to make sure that you're making devices that will work and will be sustainable

2. Suitability in our local setup because our setup might be very different from UK or US. So if we buy a machine from a first world country and bring it here, they may not exactly make it or design it to be very resilient to a harsh environment. So once you bring it here and it meets very rough floors maybe, or very harsh temperatures, or saline water, it wasn't designed with that in mind, then it gets here and meets that, it starts becoming rusty, it breaks down." CS3-01

\begin{tabular}{|c|c|}
\hline 3. Access & $\begin{array}{c}\text { "What we are doing should be accessible to common people and for that, that has to be cost } \\
\text { effective." CS2-03 }\end{array}$ \\
\hline 4. Usability & $\begin{array}{l}\text { "They would come to us and say this gauge has to be labelled this kind of way because if it's } \\
\text { done that way we have an easy time interpreting what it's saying. This handle has to be here } \\
\text { because when it's here it's easy for us to push it around." CS3-01 } \\
\text { "We don't have a lot of time to focus on learning. We want to focus more time on treating the } \\
\text { patients. So give us an equipment that is very user friendly." CS3-01 }\end{array}$ \\
\hline 5. Quality & $\begin{array}{l}\text { "We couldn't compromise on the quality ... It is unacceptable if Company X does the same } \\
\text { thing but degrades the quality." CS2-02 } \\
\text { "It has to be long-lasting in terms of the material that have been used, it has to be robust, that } \\
\text { whenever it's hit by, it may still withstand the force." CS3-01 } \\
\text { "It is the risk that it can pose to the operator or the patient that is important and we have try to } \\
\text { minimise those risks." CS3-03 }\end{array}$ \\
\hline 6. Adjustability & $\begin{array}{l}\text { "It might have some other additional features for long term sustainability, for adjustable } \\
\text { conformity. Like we have in our shoes. We have shoe laces so that we can define that tightness } \\
\text { of the shoe." CS2-02 } \\
\text { "So the ideal situation is that you should be able to replace some of the bits some of the parts, } \\
\text { without replacing the whole machine." CS3-02 }\end{array}$ \\
\hline 7. Inclusive & $\begin{array}{l}\text { "Some of them are only walking, some of them in sports, some of them are driving cars, some } \\
\text { of them are in different types of jobs, some of them in hilly regions, some of them in villages, } \\
\text { some of them in cities ... their age and body weight varies ... their usage metrics vary ... The } \\
\text { technology will allow us to create a solution for this." CS2-05 } \\
\text { "We should have a spectrum of products, and then depending on the patient's level of activity, } \\
\text { needs ... they should be able to choose from different products" CS2-12 } \\
\text { "We also need to have pressure that is acceptable. Because you place it on the baby's head. So } \\
\text { we needed to have pressures that are acceptable to pull out the baby and pressures that were } \\
\text { not going to injure the mother" CS3-07 }\end{array}$ \\
\hline 8. Complementary & $\begin{array}{l}\text { "The decisions we have made is empowering the Jaipur Foot rather than replacing it. So it can } \\
\text { be redesigned in a way that it can get attached to the Jaipur Foot." CS2-02 } \\
\text { "More importance should be given on improving designs than trying to do something totally } \\
\text { different." CS2-12 }\end{array}$ \\
\hline $\begin{array}{l}\text { 9. Local } \\
\text { manufacture }\end{array}$ & $\begin{array}{l}\text { "If this can be replicated even in the most remote part of the country, then people might have } \\
\text { access to these tools and then they might produce instantly right there when it's needed, rather } \\
\text { than making it in Kathmandu and then delivering it to other parts, which leads to this supply } \\
\text { mismatch." CS1-02 }\end{array}$ \\
\hline $\begin{array}{l}\text { 10. Local control } \\
\text { and repair }\end{array}$ & $\begin{array}{l}\text { "Because equipment that has been designed in another country ... may not work for us } \\
\text { because we don't know how to maintain them ... So we said if we made them locally then it } \\
\text { means getting spare parts would be very easy." CS3-01 } \\
\text { "The challenges we are facing concerns spares, most of the spares are not locally available. } \\
\text { Sometimes these spares take a lot of time, when we want to import from out of the country." } \\
\text { CS3-08 } \\
\text { "Most of our equipment in this hospital are not locally manufactured or assembled. So you } \\
\text { find that is a problem because if you have any problem, if they need to be serviced, then you } \\
\text { have to incur a cost to bring somebody from out there to service it." CS3-07 }\end{array}$ \\
\hline
\end{tabular}


Table A3. Cont.

\begin{tabular}{|c|c|}
\hline Factor & Exemplary Quotes \\
\hline 11. Scalable & $\begin{array}{c}\text { "That's how we come up with the different solutions which can be replicated ... which means } \\
\text { we have longer term sustainability." CS1-02 } \\
\text { "So, we want to make this to be a process, scalable, and easily replicable. That takes care of half } \\
\text { of the sustainability." CS2-03 }\end{array}$ \\
\hline 12. Collaborative & $\begin{array}{l}\text { "We recognise problems and then identify the problem and then sit together with the local } \\
\text { communities and with them look for the solutions." CS1-02 } \\
\text { "We don't have CNC, but when we want those processes in our product development, then we } \\
\text { share those problems with the other companies and then collaborate and try to fabricate it." } \\
\text { CS1-02 } \\
\text { "Different people have different ways of looking at lives ... you're given the same problem, } \\
\text { they will look at the solution from different angles. When you bring all of these angles } \\
\text { together, then you end up with a very good idea that works for everyone." CS3-01 }\end{array}$ \\
\hline 13. Transparent & $\begin{array}{l}\text { "When this model has worked, when everything is positive, then we will document it, share it } \\
\text { in the online platforms like Thingiverse ... someone in a different part of the world, they can } \\
\text { instantly download it in case they face such problems, so that someone doesn't have to work } \\
\text { on all this process." CS1-02 } \\
\text { "We are trying to think of each and every single technical detail or scientific parameter, which } \\
\text { when we document that will allow a normal welding guy to replicate the whole process." } \\
\text { CS2-03 }\end{array}$ \\
\hline 14. Advancement & $\begin{array}{l}\text { "The people who are already employed should be empowered to do that. They should not } \\
\text { suffer loss on employment because a new technology is replacing their technology." CS2-02 } \\
\text { "There is an opportunity for creation of jobs if we have it locally manufactured. There are a lot } \\
\text { of young people who will be employed here ... you also got excited because it builds capacity } \\
\text { in our students ... if as a student, you're working on something like this ... you're actually } \\
\text { learning on the job." CS3-01 }\end{array}$ \\
\hline 15. Empowerment & $\begin{array}{l}\text { "If we're doing things that then, as soon as we walk away, it all falls to bits, then that's not a } \\
\text { model." CS1-06 } \\
\text { "No, you will not give you a leg. You are giving life ... The leg is an instrument which } \\
\text { empowers him for everything around his world. He becomes a man in his own right. In his } \\
\text { own eyes, to stand up literally and figuratively on his legs. A leg is only an instrument. But the } \\
\text { change we are making to their lives is very, very important." CS2-11 }\end{array}$ \\
\hline 16. Systemic & $\begin{array}{l}\text { "We are helping other local companies and other start-ups to make 3D printers and we are } \\
\text { addressing some of the problems, like making 3D printer filaments, doing more research in } \\
\text { those fields so that we could offer more affordable and good quality 3D printer filaments } \\
\text { locally." CS1-02 } \\
\text { "And this was part of that, the aspect of proving a point that as a country we can actually } \\
\text { develop this "sophisticated equipment." We just need to give it a shot. Then create an } \\
\text { infrastructure that allows that to happen ... you don't need to import something from } \\
\text { whatever country. You have the idea, you can actually design it in your computer and you can } \\
\text { use this printer to make it." CS3-01 }\end{array}$ \\
\hline
\end{tabular}

\section{References}

1. Anheier, H.; Krlev, G.; Mildenberger, G. Social Innovation: Comparative Perspectives; Routledge: New York, NY, USA, 2019.

2. Petrick, I.J.; Simpson, T.W. 3D Printing Disrupts Manufacturing: How Economies of One Create New Rules of Competition. Res. Manag. 2013, 56, 12-16. [CrossRef]

3. Gibson, I.; Rosen, E.W.; Stucker, B. Additive Manufacturing Technologies, 3D Printing, Rapid Prototyping, and Direct Digital Manufacturing; Springer: Berlin/Heidelberg, Germany, 2015.

4. Birtchnell, T.; Hoyle, W. 3D Printing for Development in the Global South; Palgrave Macmillan: London, UK, 2014.

5. Corsini, L.; Aranda-Jan, C.B.; Moultrie, J. Using digital fabrication tools to provide humanitarian and development aid in low-resource settings. Technol. Soc. 2019, (in press). [CrossRef]

6. Esposto, S. The sustainability of applied technologies for water supply in developing countries. Technol. Soc. 2009, 31, 257-262. [CrossRef]

7. Hansson, S.O. Technology and the notion of sustainability. Technol. Soc. 2010, 32, 274-279. [CrossRef]

8. Hede, S.; Nunes, M.J.L.; Ferreira, P.F.V.; Rocha, L.A. Incorporating sustainability in decision-making for medical device development. Technol. Soc. 2013, 35, 276-293. [CrossRef] 
9. Salam, A.; Kidwai, A. A blueprint for science and technology in the developing world. Technol. Soc. 1991, 13, 389-404. [CrossRef]

10. Nichols, R.W. Perspectives on Science and Technology in Development: Does the Urgent Drive out the Important? Technol. Soc. 2007, 29, 369-377. [CrossRef]

11. Bhamra, T.; Hernandez, R.; Mawle, R.; Walker, S.; Giard, J. Sustainability: Methods and Practices. In The Handbook of Design for Sustainability; Bloomsbury Academic: London, England, 2013.

12. Archibugi, D.; Pietrobelli, C. The globalisation of technology and its implications for developing countries. Technol. Forecast. Soc. Chang. 2003, 70, 861-883. [CrossRef]

13. Pattnaik, B.K.; Dhal, D. Mobilizing from appropriate technologies to sustainable technologies based on grassroots innovations. Technol. Soc. 2015, 40, 93-110. [CrossRef]

14. Rose, E.J. Design as Advocacy: Using a Human-Centered Approach to Investigate the Needs of Vulnerable Populations. Journal of Technical Writing and Communication. Sage 2016, 46, 427-445. [CrossRef]

15. Zink, K.J. Designing sustainable work systems: The need for a systems approach. Appl. Ergon. 2014, 45, 126-132. [CrossRef] [PubMed]

16. Missimer, M.; Robèrt, K.-H.; Broman, G. A Strategic Approach to Social Sustainability—Part 2: A PrincipleBased Definition. Journal of Cleaner Production. Elsever 2016, 140, 42-52.

17. McKenzie, S. Social Sustainability: Towards Some Definitions; Hawke Research Institute Working Paper Series No 27; University of South Australia: Magill, Australia, 2004.

18. Khan, R. How Frugal Innovation Promotes Social Sustainability. Sustainability 2016, 8, 1034. [CrossRef]

19. Waage, S.A. Re-considering product design: A practical "road-map" for integration of sustainability issues. J. Clean. Prod. 2007, 15, 638-649. [CrossRef]

20. Vezzoli, C. Design for Sustainability: The New Research Frontiers. In Proceedings of the 7th Brazilian Conference on Design, Curitiba, Brazil, 9-11 August 2006; pp. 83-106.

21. Joyce, A.; Paquin, R.L. The triple layered business model canvas: A tool to design more sustainable business models. J. Clean. Prod. 2016, 135, 1474-1486. [CrossRef]

22. Stark, R.; Buchert, T.; Neugebauer, S.; Bonvoisin, J.; Finkbeiner, M. Benefits and obstacles of sustainable product development methods: A case study in the field of urban mobility. Des. Sci. 2017, 3, 17. [CrossRef]

23. United Explanations. The Story of PlayPumps: Merry-Go-Rounds, Water, and Failures in Development Aid. Available online: http://unitedexplanations.org/english/2012/03/22/the-story-of-playpumps-merry-gorounds-water-and-failures-in-development-aid/ (accessed on 18 June 2019).

24. Brocklehurst, C.; Harvey, P. An Evaluation of the Playpump Water System as an Appropriate Technology for Water, Sanitation and Hygiene Programmes; UNICEF: New York, NY, USA, 2012.

25. Becker, E.; Jahn, T.; Stieß, I. Exploring Uncommon Ground: Sustainability and the Social Sciences. In Sustainability and the Social Sciences: A Cross-Disciplinary Approach to Integrating Environmental Considerations into Theoretical Reorientation; Zed Books: London, UK, 1999; p. 20.

26. Littig, B.; Griessler, E. Social sustainability: A catchword between political pragmatism and social theory. Int. J. Sustain. Dev. 2005, 8, 65. [CrossRef]

27. El Ebrashi, R. Social entrepreneurship theory and sustainable social impact. Soc. Responsib. J. 2013, 9, $188-209$. [CrossRef]

28. Von Geibler, J.; Liedtke, C.; Wallbaum, H.; Schaller, S. Accounting for the social dimension of sustainability: Experiences from the biotechnology industry. Bus. Strat. Environ. 2006, 15, 334-346. [CrossRef]

29. Spangenberg, J.H.; Omann, I. Assessing social sustainability: Social sustainability and its multicriteria assessment in a sustainability scenario for Germany. Int. J. Innov. Sustain. Dev. 2006, 1, 318. [CrossRef]

30. Bebbington, J.; Dillard, J. Social Sustainability: An Organizational-Level Analysis. In Understanding the Social Aspect of Sustainability; Dillard, J., Dujon, V., King, M.C., Eds.; Routledge: New York, NY, USA, 2009; pp. 157-173.

31. Eizenberg, E.; Jabareen, Y. Social Sustainability: A New Conceptual Framework. Sustainability 2017, 9, 68. [CrossRef]

32. Benoît, C.; Norris, G.A.; Valdivia, S.; Ciroth, A.; Moberg, Å.; Bos, U.; Prakash, S.; Ugaya, C.; Beck, T. The guidelines for social life cycle assessment of products: Just in time! Int. J. Life Cycle Assess. 2010, 15, 156-163. [CrossRef]

33. Whitely, N. Design for Society; Recktion Books: London, UK, 1993. 
34. Cooley, M. Socially Useful Design: A Form of Anticipatory Democracy. Econ. Ind. Democr. 1986, 7, 553-559. [CrossRef]

35. Cooper, R. Ethics and Altruism: What Constitutes Socially Responsible Design? Des. Manag. Rev. 2005, 16, 10-18. [CrossRef]

36. de Vere, I.; Johnson, K.B.; Thong, C. Educating the Responsible Engineer: Socially Responsible Design and Sustainability in the Curriculum. In Proceedings of the International Conference on Engineering and Product Design Education, Brighton, UK, 10-11 September 2009; p. 6.

37. Caruso, C.; Frankel, L. Everyday People: Enabling User Expertise in Socially Responsible Design. In Proceedings of the 2010 Design Research Society Montreal Conference, Design \& Complexity, Montreal, QC, Canada, 7-9 July 2010.

38. Diehl, J.C. The First Learning Experience of Designing for the BoP. Available online: https://www.sd.polyu.edu.hk/ iasdr/proceeding/papers/The \%20first $\% 20$ learning\%20experiences $\% 20$ of $\% 20$ Design $\% 20$ for $\% 20$ the $\% 20$ BoP.pdf (accessed on 28 June 2019).

39. Koo, Y.; Cooper, R. What Drives Socially Responsible Design in Organizations?: Empirical Evidence from South Korea. Des. J. 2016, 19, 879-901. [CrossRef]

40. Gould, R.; Missimer, M.; Mesquita, P.L. Using social sustainability principles to analyse activities of the extraction lifecycle phase: Learnings from designing support for concept selection. J. Clean. Prod. 2017, 140, 267-276. [CrossRef]

41. Ehrenfeld, J.R. Sustainability by Design; Yale University Press: New Haven, CT, USA, 2008.

42. McMahon, M.; Bhamra, T. 'Design Beyond Borders': International Collaborative Projects as a Mechanism to Integrate Social Sustainability into Student Design Practice. J. Clean. Prod. 2011, 23, 86-95. [CrossRef]

43. Brundtland, G.H.; Khalid, M.; Agnelli, S.; Al-Athel, S. Our Common Future; Oxford University Press: New York, NY, USA, 1987.

44. Margolin, V.; Margolin, S. A "Social Model” of Design: Issues of Practice and Research. Des. Issues 2002, 18, 24-30. [CrossRef]

45. Hillgren, P.-A.; Seravalli, A.; Emilson, A. Prototyping and infrastructuring in design for social innovation. CoDesign 2011, 7, 169-183. [CrossRef]

46. Papanek, V.J. Design for the Real World: Human Ecology and Social Change; Academy Chicago; Pantheon Books: New York, NY, USA, 1985.

47. Braun, V.; Clarke, V. Using thematic analysis in psychology. Qual. Res. Psychol. 2006, 3, 77-101. [CrossRef]

48. Gebru, K.; Leung, M.; Rammelt, C.; Zoomers, A.; van Westen, G. Vegetable Business and Smallholders' Food Security: Empirical Findings from Northern Ethiopia. Sustainability 2019, 11, 743. [CrossRef]

49. Daengbuppha, J.; Hemmington, N.; Wilkes, K. Using grounded theory to model visitor experiences at heritage sites: Methodological and practical issues. Qual. Mark. Res. Int. J. 2006, 9, 367-388. [CrossRef]

50. Yin, R.K. Case Study Research and Applications: Design and Methods; Sage: Los Angeles, CA, USA, 2018.

51. Saldaña, J. The Coding Manual for Qualitative Researchers; Sage: Los Angeles, CA, USA, 2009.

52. Thomas, A. Design, Poverty, and Sustainable Development. Des. Issues 2006, 22, 54-65. [CrossRef]

53. Lilley, D. Design for sustainable behaviour: Strategies and perceptions. Des. Stud. 2009, 30, 704-720. [CrossRef]

54. Manzini, E. Making Things Happen: Social Innovation and Design. Des. Issues 2014, 30, 57-66. [CrossRef]

55. Millard, J.; Sorivelle, M.N.; Deljanin, S.; Unterfrauner, E.; Voigt, C. Is the Maker Movement Contributing to Sustainability? Sustainability 2018, 10, 2212. [CrossRef]

56. Cappa, F.; Del Sette, F.; Hayes, D.; Rosso, F. How to Deliver Open Sustainable Innovation: An Integrated Approach for a Sustainable Marketable Product. Sustainability 2016, 8, 1341. [CrossRef]

57. Savastano, M.; Amendola, C.; Bellini, F.; D'Ascenzo, F. Contextual Impacts on Industrial Processes Brought by the Digital Transformation of Manufacturing: A Systematic Review. Sustainability 2019, 11, 891. [CrossRef]

58. Morelli, N. Social Innovation and New Industrial Contexts: Can Designers "Industrialize" Socially Responsible Solutions? Des. Issues 2007, 23, 3-21. [CrossRef]

59. Morelli, N. Design as a problem and design as a solution for sustainability. Int. J. Innov. Sustain. Dev. 2012, 6, 265. [CrossRef]

60. Boyer, R.H.W.; Peterson, N.D.; Arora, P.; Caldwell, K. Five Approaches to Social Sustainability and an Integrated Way Forward. Sustainability 2016, 8, 878. [CrossRef] 
61. Montabon, F.L.; Pagell, M.; Wu, Z. Making Sustainability Sustainable. J. Supply Chain Manag. 2016, 52, 11-27. [CrossRef]

62. Bhamra, T.; Lofthouse, V. Design for sustainability: A practical approach; Routledge: New York, NY, USA, 2016.

63. Melles, G.; De Vere, I.; Misic, V. Socially responsible design: Thinking beyond the triple bottom line to socially responsive and sustainable product design. CoDesign 2011, 7, 143-154. [CrossRef]

64. Stairs, D. Altruism as Design Methodology. Des. Issues 2005, 21, 3-12. [CrossRef]

65. Bezerra, C.; Brasell-Jones, M. Design Responsibility in Global Open Societies; University of Arts \& Design: Helsinki, Finland, 2005; p. 7.

66. Bjögvinsson, E.; Ehn, P.; Hillgren, P.-A. Design Things and Design Thinking: Contemporary Participatory Design Challenges. Des. Issues 2012, 28, 101-116. [CrossRef]

67. Manzini, E.; Rizzo, F. Small projects/large changes: Participatory design as an open participated process. CoDesign 2011, 7, 199-215. [CrossRef]

68. Thorpe, A.; Gamman, L. Design with society: Why socially responsive design is good enough. CoDesign 2011, 7, 217-230. [CrossRef]

69. Smith, R.C.; Iversen, O.S. Participatory design for sustainable social change. Des. Stud. 2018, 59, 9-36. [CrossRef]

70. Kang, L. The Case of a Handcraft Pottery Community in Cambodia. Int. J. Des. 2016, 10, 65-74.

71. Kapoor, I. The Postcolonial Politics of Development; Informa UK Limited: London, UK, 2008.

72. Er, Ö.; Kaya, Ç. Problems or Opportunities?: Overcoming the Mental Barrier for Socially Responsible Design in Turkey. Des. J. 2008, 11, 159-181.

73. Charnley, F.; Lemon, M.; Evans, S. Exploring the process of whole system design. Des. Stud. 2011, 32, $156-179$. [CrossRef]

74. Blizzard, J.L.; Klotz, L.E. A framework for sustainable whole systems design. Des. Stud. 2012, 33, 456-479. [CrossRef]

75. Freeman, C.; Perez, C. Structural Crises of Adjustment, Business Cycles and Investment Behaviour. Technical Change and Economic Theory. In Technical Change and Economic Theory, 1st ed.; Dosi, G., Freeman, C., Nelson, R., Silverberg, G., Soete, L., Eds.; Pinter Publishers: London, UK, 1988; pp. 38-66.

76. Geels, F.W.; Schot, J. Typology of sociotechnical transition pathways. Res. Policy 2007, 36, 399-417. [CrossRef]

77. Savaget, P.; Geissdoerfer, M.; Kharrazi, A.; Evans, S. The Theoretical Foundations of Sociotechnical Systems Change for Sustainability: A Systematic Literature Review. J. Clean. Prod. 2019, 206, 878-892. [CrossRef]

78. Clark, G.; Kosoris, J.; Hong, L.N.; Crul, M. Design for Sustainability: Current Trends in Sustainable Product Design and Development. Sustainability 2009, 1, 409. [CrossRef]

79. Manzini, E.; Vezzoli, C. A strategic design approach to develop sustainable product service systems: Examples taken from the 'environmentally friendly innovation' Italian prize. J. Clean. Prod. 2003, 11, 851-857. [CrossRef]

80. Howarth, G.; Hadfield, M. A sustainable product design model. Mater. Des. 2006, 27, 1128-1133. [CrossRef]

81. de Vere, I.; Kapoor, A.; Melles, G. An Ethical Stance: Engineering Curricula Designed for Social Responsibility. In DS 68-8: Proceedings of the 18th International Conference on Engineering Design (ICED 11), Impacting Society through Engineering Design; Design Education: Lyngby/Copenhagen, Denmark, 2011; Volume 8, p. 10.

82. Chick, A. Design for Social Innovation: Emerging Principles and Approaches. Iridescent 2012, 2, 78-90. [CrossRef]

83. Cipolla, C.; Bartholo, R. A Dialogical Approach to Socially Responsible Design. Int. J. Des. 2014, 8, 14.

84. Vezzoli, C.; Ceschin, F.; Diehl, J.C.; Kohtala, C. New design challenges to widely implement 'Sustainable Product-Service Systems'. J. Clean. Prod. 2015, 97, 1-12. [CrossRef]

85. Ceschin, F.; Gaziulusoy, I. Evolution of design for sustainability: From product design to design for system innovations and transitions. Des. Stud. 2016, 47, 118-163. [CrossRef]

86. Koskinen, I.; Hush, G. Utopian, Molecular and Sociological Social Design. Int. J. Des. 2016, 10, 7.

87. Gamman, D.L.; Thorpe, A. Design Against Crime as Socially Responsive Theory and Practice. In Proceedings of the 9th International Design Conference, Dubrovnik, Croatia, 15-18 May 2006; pp. 721-732.

88. Maxwell, D.; Van Der Vorst, R. Developing sustainable products and services. J. Clean. Prod. 2003, 11, 883-895. [CrossRef]

89. Dewulf, W. Design for Sustainability-Anticipating the Challenge. In Proceedings of the ICED 03, Stockholm, Sweden, 19-21 August 2003; pp. 233-234. 
90. Hanusch, D.; Birkhofer, H. Creating Socially Sustainable Products-Examinating Influence and Responsibility of Engineering Designers. In Proceedings of the DESIGN 2010, Dubrovnik, Croatia, 17-20 May 2010; pp. 771-778.

91. Amatullo, M.; Becerra, L.; Montgomery, S. Designmatters Case Studies: Design Education Methodologies as a Tool for Social Innovation. In Proceedings of the Open, the Annual Conference, Washington, DC, USA, 24-26 March 2010; pp. 1-17.

92. Kadir, S.A.; Jamaludin, M. Universal Design as a Significant Component for Sustainable Life and Social Development. Procedia-Soc. Behav. Sci. 2013, 85, 179-190. [CrossRef]

93. Yee, J.S.R.; White, H. The Goldilocks Conundrum: The 'Just Right' Conditions for Design to Achieve Impact in Public and Third Sector Projects. Int. J. Des. 2016, 10, 13.

94. Manzini, E. The New Way of The Future: Small, Local, Open And Connected. Available online: https: //pdfs.semanticscholar.org/2dce/b9b5ba8293a530ed0de01ea726afed648cc1.pdf (accessed on 28 June 2019).

95. Margolin, V. Design for a Sustainable World. Des. Issues 1998, 14, 83. [CrossRef]

96. Asheim, J.; Kjøllesdal, A.; Boks, C. Coming of Age as Design (Er) for Social Sustainability. In Proceedings of the 14th International Conference on Engineering \& Product Design Education (E\&PDE12) Design Education for Future Wellbeing, Antwerp, Belguim, 6-7 September 2012; pp. 525-530.

97. Manzini, E. Design in the transition phase: A new design culture for the emerging design. Des. Philos. Pap. 2015, 13, 57-62. [CrossRef]

98. Melles, G.; Kuys, B.; Kapoor, A.; Rajanayagam, J.; Thomas, J.; Mahalingam, A. Designing Technology, Services and Systems for Social Impact in the Developing World: Strong Sustainability Required. In ICoRD'15Research into Design Across Boundaries Volume 2; Chakrabarti, A., Ed.; Springer India: New Delhi, India, 2015.

99. Chen, D.-S.; Cheng, L.-L.; Hummels, C.; Koskinen, I. Social Design: An Introduction. Social Design. Int. J. Des. 2016, 10, 6.

100. Lie, I.K. 'Make Us More Useful to Society!': The Scandinavian Design Students' Organization (SDO) and Socially Responsible Design, 1967-1973. Des. Cult. 2016, 8, 327-361. [CrossRef]

101. Mendoza, J.M.F.; Gallego-Schmid, A.; Rivera, X.C.S.; Rieradevall, J.; Azapagic, A. Sustainability assessment of home-made solar cookers for use in developed countries. Sci. Total. Environ. 2019, 648, 184-196. [CrossRef]

102. Sklar, A.; Madsen, S. Global Ergonomics: Design for Social Impact. Ergon. Des. Q. Hum. Factors Appl. 2010, 18, 4-31. [CrossRef]

103. Gmelin, H.; Seuring, S. Determinants of a sustainable new product development. J. Clean. Prod. 2014, 69, 1-9. [CrossRef]

104. McMahon, M.; Bhamra, T. Social Sustainability in Design: Moving the Discussions Forward. Des. J. 2015, 18, 367-391. [CrossRef]

105. Haug, A. Educating Ethical Designers. Int. J. Technol. Des. Educ. 2017, 27, 655-665. [CrossRef]

106. Schaber, F. Socially Responsible Design: Breadline Shoes for Children in India. In Proceedings of the E\&PDE 2010 the 12th International Conference on Engineering and Product Design Education-When Design Education and Design Research Meet, Trondheim, Norway, 2-3 September 2010; pp. 352-357.

107. Koo, Y. The Role of Designers in Integrating Societal Value in the Product and Service Development Processes. Int. J. Des. 2016, 10, 17.

108. Woodcraft, S. Understanding and measuring social sustainability. J. Urban Regen. Renew. 2015, 8, $133-144$.

(C) 2019 by the authors. Licensee MDPI, Basel, Switzerland. This article is an open access article distributed under the terms and conditions of the Creative Commons Attribution (CC BY) license (http://creativecommons.org/licenses/by/4.0/). 